\title{
3 \\ - \\ Village rebellion and social violence in early nineteenth-century Vietnam
}

\author{
Vũ Đức Liêm
}

Ban cung sinh dao tac.

Misery creates banditry.

(Vietnamese proverb)

In summer 1834, Nguyen Khac Hai, the lieutenant governor of Bac Ninh province (forty kilometres to the north of Hanoi), led a mission to inspect local dykes. In the middle of the tour, Hai was ambushed by armed men who came to be known in the imperial records as 'bandits' ( $p h i) .{ }^{1}$ Taken by surprise, most of Hai's escort of officials and troops were killed before he retreated to a nearby village to summon help. Contrary to his expectations, the villagers not only refused, but closed the gates, trapping Hai outside where he was killed. Minh Menh (r. 1820-41), the second emperor from the Nguyen dynasty ruling unified Vietnam since 1802, was furious that his imperial subjects had 'sat and watched' while Hai, a third-grade mandarin (on the nine-point scale) appointed by himself, had been butchered. Imperial retaliation was swift: of the 'bandits' and village gatekeepers, twenty were executed and ten exiled. ${ }^{2}$

The monarch's fury deserves an explanation. Ruling the realm as emperor and regarding himself as 'Son of Heaven' (thien tu), Minh Menh was born with the belief that 'under the Heaven there is no land that is not the emperor's land; there are no subjects who are not the emperor's subjects'. ${ }^{3}$ In that world, opposing the state was a severe act of rebellion subject to severe legal penalties. ${ }^{4}$ The 1834 incident, however, was among many that haunted Hue's rule over thousands of villages in northern Vietnam. The influx of landless peasants and hungry migrants into the region generated waves of social violence, undermining the dynasty's 
control over villages, the basic form of social organization. The violence sweeping the empire in the mid 183 os posed the first truly existential crisis since the dynasty's foundation, and prompted military retaliation on a massive scale. ${ }^{5}$ After seemingly endless pacification campaigns, the emperor demonstrated his determination to end all further treasonous behaviour by 'cultivation' (giao hoa) of his subjects. One month after the Bac Ninh's assault, the lengthy and carefully drafted Ten Moral Maxims were disseminated to every village to serve as a benchmark for proper behaviour. ${ }^{6}$ The Instruction showed Hue's awareness of the epidemic violence in the Red River Delta and potential threat of further uprisings across this densely populated region. ${ }^{7}$

This is a story of local militarization, social violence, and deterioration of central power in early modern Vietnam. It demonstrates how human mobilization, facilitated by the development of regional militias, weakened the central state and provided a breeding ground for social disorder and violence. Local gentry exploited the state's Achilles heel of administrative and military weakness and built up transregional networks across twelve provinces in northern Vietnam. The situation was more complex than Charles Tilly's formulation that 'war made the state and the state made war. ${ }^{8}$ In this story, the state's attempt to arm itself against social revolt impaired the traditional centralized authority and encouraged gentry-led fragmentation on the eve of Western colonialization.

In illuminating these developments, this chapter examines the role violence plays in shaping human organization. It argues that local militarization, as the most significant sociopolitical phenomenon in early nineteenth-century Vietnam, severely challenged the Nguyen state and fuelled violence across the realm. Aiming to reduce the scale of insurrection, Hue mobilized troops to suppress rebellions and exile captured rebels. The strategy proved counterproductive as social discontent spread to involve the highland communities, rural peasants, coastal Christians, and Lower Mekong Khmer. ${ }^{9}$

Among the dynasty's key failures were the loss of control over local militias and shifting demographic geography. The interaction between 'human mobility', 'violence', and 'state-power devolution' transformed Vietnamese politics, undermining traditional-style statecraft during the 1830s. Minh Menh's projection of administrative centralization, territorialization, and cultural assimilation stirred tremendous local hostility towards the central elite. The local gentry were drawn into politics, shifting the balance of power between the centre and localities and threatening the survival of both dynasty and state. By focusing on the militias and local violence, this chapter offers new insights into the social and political character of early modern Vietnam. In doing so, it reappraises the role of coercion in the decline of traditional political structures as part of a longer-term social and political change linking the early Nguyen to the broad trends of Vietnam's modern history.

The modern state, as defined by Max Weber, is 'a human community that 
(successfully) claims the monopoly of the legitimate use of physical force within a given territory'. ${ }^{10}$ The Nguyen certainly claimed a monopoly of legitimate coercion by labelling all others who used violence as 'bandits'. This assertion of authority by no means came close to the dynamic nature of the actual violence. 'Calling someone or some group a bandit lays bare a political language that otherwise dresses violence in the drag of civilization. ${ }^{11}$ However, 'until the lion can tell his own stories, tales of the hunt will be told by the hunter.'. ${ }^{12}$

This chapter is a search for the lion's lost voice. It looks for the village's way of making violence in response to a waning state. The dominant state-centric narratives generally see 'banditry' as a defined and homogeneous form of social insurgency. By contrast, this chapter investigates the role violence plays as a form of human interaction. The more Hue attempted to assert its monopoly, the further violence spread across the Red River Delta. Here, this chapter challenges the conventional nationalist interpretation of villages' historical role. Inspired by nostalgia and romanticism, the rural landscape is presented as a harmonious, peaceful world, and a reservoir of beautifully traditional values. The labouring peasants are depicted as kindly, peace-lovers who supported revolutionaries against an oppressive elite. In contrast, the following pages reveal the 'rebellious' character of that rural world and recognize that the countryside was a major source of social violence.

\section{State and village in Vietnam, 1500-1800}

The king's law bows to the village's rules.

(Vietnamese proverb)

The French scholar Paul Mus argues that 'Since time immemorial, these villages have become the key to the social structure of the country and to its outlook on life.' ${ }^{3}$ The Nguyen rulers clearly thought the same. Emperor Gia Long declared, 'the state is constituted by villages'. ${ }^{14}$ The countryside was where most of the population dwelled, most taxes were collected, and most soldiers were conscripted.

The relatively low level of economic exchange and limited human mobility encouraged past historians to voice two firmly held views. First, that Vietnam's villages protected their country's identity throughout a thousand years of upheaval because no 'foreign influence' could penetrate their firmly self-contained structure. Second, that the villages could be turned into effective military fortresses to oppose foreign invaders. In other words, they were invincible foundations of culture and the source of social security, where the best Vietnamese values resided. This conventional view accords with the scholarly emphasis on socio-economic durability. Empires and dynasties came and went, but the villages remained in the same place with the same name. These conclusions underpin the historical asser- 
tion that ethnic Viet prevailed in eastern mainland Southeast Asia because of the power of their villages that allowed Vietnamese colonization of Central Vietnam and Lower Mekong between 1400 and 1850 . The villages' way of social formation and economic production qualified the Vietnamese who 'flowed across Indochina like a flood carrying off other peoples wherever they occupied lowland rice fields or where it could be put under rice'. ${ }^{15}$

In reality, villagers' behaviour, however, was not always peaceful and constructive. Shifting demography, natural disasters, and political suppression spurred frequent unrest across the rural world. The Red River Delta during the last eight centuries witnessed considerable human mobility. Three million people left the basin in the fifteenth century alone. ${ }^{16}$ However, the region remained among the most densely populated deltas in the world. ${ }^{17}$ Village structure and its relationship to the state were also dramatically transformed. The decline of nobles' estates in the fourteenth century changed the rural economy by creating a market in which communal land could be bought or sold, and thus turned into private property. ${ }^{18}$ The spread of private land ownership and the emergence of influential regional families clashed with the state's agenda of turning villages into administrative institutions by maintaining a good ratio of communal to private land to support taxation, corvée labour, and military conscription. Such balance was the foundation of state stability and social security. ${ }^{19}$ The growing concentration of rural land in the hands of local elites broke the statevillage balance, triggering a decline in the central authority based in Hanoi, and prompting incessant warfare between 1527 and 1802 . The coincidence of division in the political centre and militarization of the countryside through rural militias turned 'the capital into fishing zone and hunting ground', as stated by the dynastic chronicle. $^{20}$

The Nguyen family, which ruled after 1802, began their rise to power as loyalists of the Le dynasty ruling Vietnam from 1428 to 1788 . Internal conflict divided the Nguyen and one member left to found the autonomous Cochinchinese state in Central Vietnam. ${ }^{21}$ From that domain, however, one of its rulers, Nguyen Phuc Anh, finally claimed supremacy over all Vietnamese and declared himself Gia Long emperor (1802-20). As a southern warlord, he viewed the hostile north with suspicion. Northerners, meanwhile, regarded the Nguyen as frontier officials who had rebelled against the Hanoi-based Le emperors. Furthermore, the Nguyen army arrived in Hanoi when the delta inhabitants had already tasted the bitterness of many bad governments and therefore opposed all state power. ${ }^{22}$ As the chief victims of the turbulence between 1750 and 1802 , villagers increasingly regarded the state as an 'enemy' rather than a 'protector'. Under the Tayson period (1770-1802), for instance, the delta was ruled by a non-local and military-oriented regime whose extraction of soldiers, corvée labour, and resources exhausted the river basin. However, worse was to come as the Nguyen era heralded further misery, flooding, famine, and violence. ${ }^{23}$ 


\section{Village bullies, local strongmen, and rural militarization}

At the root of rural violence were two social archetypes who were not necessarily mutually exclusive: 'village bullies' (hao) and 'local strongmen' (tho hao). Their possession of political and economic power dominated rural society through direct manipulation of peasant life and their authority ranged from organizing village defence to creating surtaxes and conducting land-grabbing. They were very familiar with violence. In 1485 , Le dynastic records already mentioned 'epidemic local bullying' and ordered those responsible to be subjected to the law. ${ }^{24}$ Hue's failure to govern the villages after 1802 , however, led to unprecedented hardship.

The unique nature of Nguyen administration allowed early nineteenth-century local gentry more space to exercise their dominance over the countryside. First, the state law code enforced in 1813 was largely based on that of the Qing, which was designed for the Manchu's minority rule over the majority Han ethnics. ${ }^{25}$ That legal framework offered considerable autonomy to villages. Gia Long's son, Emperor Minh Menh (r. 1820-41), realized the danger and ordered the Code revised, but this was never fully completed. ${ }^{26}$ Secondly, both rulers treated northern Vietnam lightly, fearing its disloyalty, hostility, and military threat. Based in the capital Hue, a relatively small city occupying a narrow coastal strip, Gia Long was poorly placed to manage the two economic and demographic powerhouses of the Red River Delta and Mekong basin, which were $700 \mathrm{~km}$ to the north and a $1,000 \mathrm{~km}$ to the south respectively. ${ }^{27}$ The most obvious challenge was to mobilize resources and troops for administrative operations and military campaigns.

The power vacuum opening in the countryside was immediately exploited by local chiefs across the northern delta where the office of governor-general (tong tran) was established. Militias had emerged between the 1780 s and 1800 to protect northern villages during the constant shifts of power in Hanoi. Regardless of whether they supported or opposed the Nguyen, all quickly exploited the new imperial dynasty's weakness to squeeze more resources from the rural population. After 1802, some cooperated with Hue in suppressing revolts and banditry. They came to be known as 'local chiefs' (tho hao). Their followers were hired as local troops (tho binh), guarding posts, traffic roads, and protecting villages. ${ }^{28}$ By the 1810s, local militias took great responsibilities for the delta's security, both along the coasts and the highland corridor stretching from Nghe An to Son Tay, and after Gia Long's death (1820) they were ordered to assist metropolitan troops, station strategic traffic routes, and monitor vulnerable villages. ${ }^{29}$

Those opposing the state were officially castigated as 'bandits' ( $p h i)$. It is clear that the state saw the 'local bullies' controlling these militias as their greatest competitor in the rural world. ${ }^{30}$ In an edict issued in 1827 , following the Phan Ba Vanh rebellion (1821-27), Hue analysed the violent nature of the Red River Delta where rural bullies were accused of manipulating local officials and exercising coercion 
over poor villagers. ${ }^{31}$ Yet the state simultaneously depended on local militias to provide security, collect taxes, and fight Chinese pirates. ${ }^{32}$

This strategy had serious unforeseen consequences in allowing local soldiers to play a bigger role, while legitimating the militarization of the delta villages and fuelling the growth of decentralized, autonomous warfare. The move immediately alarmed provincial officials who saw legitimate local militarization as threatening state security. There was, however, little they could do, particularly after the accession of Minh Menh. The menacing prospect of violence remained, including the emergence of those claiming loyalty to the displaced Le dynasty. ${ }^{33}$ In Thanh Hoa and Ninh Binh, between 1816 and 1836, several groups proclaimed loyalty to the dethroned family and recruited thousands of armed men along a $250 \mathrm{~km}$ corridor of midland from Nghe An to Son Nam. For instance, the so-called 'bandit' leader Nguyen The Chung, the son of a doctoral-degree holder, proclaimed himself 'commander general' of Son Nam in $1822 .{ }^{34}$

The alarming violence was also fuelled by the collusion between corrupt officials and rural law-breakers. One prefect from Son Tay reportedly provided money to the outlaws who kidnapped villagers and placed them outside the city's wall. Pretending the victims were rebels, the official went on to execute them and reported to Hue for promotion. ${ }^{35}$ The active and practical mandarin, Nguyen Cong Tru (1778-1858), was aware of the linkage between local bullies and social violence. From 1826, he was authorized by Minh Menh to pacify the delta. As governor-general of Hai Duong, the delta's flooding hub, Tru was greatly concerned by the villagers' economic condition and saw the danger posed by the untamed local bullies and militias. In a long and carefully analysed memorial, he suggested that regional chiefs and their hired men should be replaced by metropolitan troops for security duties. ${ }^{36}$ Three months later, the Board of Revenue initiated new discussions on military expense and questioned local forces' efficiency in economic and security terms. ${ }^{37}$ Unfortunately, Hue lacked any viable alternative to the local forces and was forced to continue its policy of sanctioning rural militarization.

The Phan Ba Vanh insurgency demonstrated how the interaction of rural militarization and local power struggles could encourage the escalation and spread of violence. During his rebellion against Minh Meng in 1826, Phan Ba Vanh, a native of Minh Giam village, mobilized 5,000 men from the rim of the river basin. ${ }^{38}$ This midland area of Thai Nguyen, Hung Hoa, Son Tay, Ninh Binh, and Thanh Hoa, sandwiched between the lowlands and mountains, had experienced a rapid growth in militias and local bullies who received monthly payments of copper coins and grain from the court. ${ }^{39}$ Unsurprisingly, the same area was also the cradle for most of the revolts between 1832 and 1837. In 1835, Minh Menh finally ordered a comprehensive inspection of the delta's militias. Only fifty-three local guard posts were retained, and their garrisons were limited to fifty armed men each. ${ }^{40}$ This measure was intended to extend monarchical authority over the local forces by merging 
them with the metropolitan army, with the militia leaders receiving official titles and the armed men becoming state soldiers. ${ }^{41}$

\section{The source of weaponry}

Rising social violence was fuelled by new sources of modern weapons pouring into rural communities. The highlanders played important roles in this supply chain providing locally made muskets (dieu thuong) and gunpowder. Alarmed by this lowland-highland weapon exchange, Minh Menh declared that the number of confiscated guns had reached tens of thousands by 1837.42 The increasing availability of modern firearms had been a steady trend since the Tayson regime, however. Local militias along the coastline, for instance, had been heavily armed since the late eighteenth century when they encountered Chinese pirates operating from the maze of islands and costal terrain stretching from Fukien (China) to the Gulf of Tonkin. ${ }^{43}$ There they received the Tayson's protection, whose patronage encouraged piracy penetration into the delta's porous coastline. ${ }^{44}$

The regional network of weapon exchange was a major source of the arms used by local forces to attack the state's own army. The number of confiscated firearms gives some indication of the rebel armaments. In 1837, 1,500 muskets and six cannons were reportedly handed over voluntarily after a campaign in Ninh Binh, indicating just how prevalent firearms were in the delta and its surrounding highlands. ${ }^{45}$ Phan Ba Vanh was able to capture large numbers of weapons from the government, as well as gather up to 200 ships and construct a fortress to resist a major court army's siege. ${ }^{46}$

The spread of Western-style weapons prompted Minh Menh to ban firearm sales in summer 1837 , arguing that muskets were useful military equipment, but were harmful if they fell into civilian hands. Knowing that most of these weapons were made locally, he warned local officials to remain alert to gunmaking in their jurisdiction and threatened producers with the death penalty. ${ }^{47}$ The measures were extended to gunpowder later that year, when all sulphur and saltpetre mines along the Sino-Vietnamese border were closed. The gunpowder trade was banned in the northern region, and those owning more than 600 grams were threatened with severe penalties. ${ }^{48}$

\section{Human mobility and rural militarization}

Northern Vietnam experienced considerable demographic fluctuations during early modernity, with a significant exodus of peasants from the provinces along the Red River's northern bank due to natural disasters and seasonal migration. ${ }^{49}$ These movements spread not only hunger and disease, but violence too. Whether a product of state design (displacement of native soldiers and exiled prisoners) or involuntary waves of starving famers, migration facilitated both regional conflicts and 
opportunities for transregional insurrection. In this environment, local militias became both highly mobile and trans-provincial.

The state's practice of forcible relocation complicated the demographic picture. One form was the posting of large numbers of troops recruited in the north to duties in the south. ${ }^{50}$ Many of these troops were former rebels or bandits. Another was the growing use of exile to punish criminals and outlaws. The Nguyen legal code offered five categories of punishments, with exile (luu) placed second after the death penalty. The practice offered provincial officials a seemingly easy way of ridding themselves of troublemakers and thus boosting the numbers into the thousands each year. However, it simply shifted the problem to other regions, while unintentionally forging transregional networks among displaced former outlaws.

A third form was the impressment of captured rebels and bandits. Ringleaders were generally executed, but their followers were commonly drafted into the state army. Ostensibly, this strategy asserted control over thousands of non-registered males and outlaws who were now legible to the state radar. In reality, it furthered the process of political decentralization, because the loyalties of those former bandits and rebels shifted not to the state, but to the general who pardoned them and tolerated their continued wicked behaviour. Their deployment to remote provinces provided opportunities for them to spread violence elsewhere, especially if they later deserted.

This practice developed in two stages, beginning with the drafting of local men, including outlaws and convicts, to make up for the lack of conscripts. Dispatched to Nghe An and Thanh Hoa to suppress rebels, Hue's most powerful generals, Le Van Duyet and Le Chat, saw an opportunity to expand their own forces. Nine hundred 'bandits' turned themselves in at Duyet's camp in 1819 and were promptly formed into four new divisions optimistically titled 'Thanh Hoa-obedience', 'Northern obedience', 'Nghe An-obedience', and 'Returning to goodness' ${ }^{51}$ Chat even pardoned criminals and encouraged local militias to recruit men and join his army directly by awarding titles to local leaders according to how many men they could find. ${ }^{52}$ Such exercises offered ambitious generals a quick route to victory and the chance to win favour and reward at court.

Despite these obvious problems, Minh Menh pressed ahead with this practice after 1820 and sent Duyet's new divisions to the Lower Mekong. However, the complication of maintaining such troops soon became apparent as many simply ran away. ${ }^{53}$ As Minh Menh's adviser noted, the policy was unfeasible because the bandits were the 'neighbours and relatives' of the people where they had been posted. ${ }^{54}$ By 1824, Minh Menh decided to station all soldiers outside their home area. Subsequently, dislocation of the exiled and surrendered bandits became a crucial part of Hue's pacifying strategy. Although the king was aware of the potential risks when moving those 'rebels' around, his officials believed they could monitor them by threatening deserters with death. Results fell far short of expectations. Insurgency returned to Thanh Hoa, Ninh Binh in 1826, 1827, 1828, 1833, 
1835, and 1836. The Le Van Khoi rebellion in the Lower Mekong in 1833 amply demonstrated the problem: thousands of Christians, Chinese, highlanders, exiled prisoners, and deserters gathered within a week and controlled the southern administration for three years, before being brutally suppressed. ${ }^{55}$ By 1834 , facing empire-wide insurrection, Minh Menh called on provincial officials to change their practices and blamed his generals for recruiting and patronizing treacherous troublemakers. ${ }^{56}$ Much of the emperor's complaint was true, but Hue was to a large extent itself responsible for initiating the policy. ${ }^{57}$

Lack of conscripted men was a major factor behind this. ${ }^{58}$ When Le Chat requested permission to collect local male residents in Hung Hoa, Minh Menh had no choice but to approve..$^{59}$ Despite official efforts, many dodged the draft, including those who were not registered or had become outlaws. ${ }^{60}$ Even men who were recruited often subsequently decamped, with the desertion rate reaching an alarming 50 per cent by late $1826 .{ }^{61}$ This put more pressure on conscription and the need to maintain southern troops in the north. The state treasury was the first to feel the effects when the Board of Revenue reported insufficient grain for the soldiers' salary and asked provincial officials to provide assessments of those local troops' efficiency. ${ }^{62}$ The demand was certainly not the last, but the dynasty was unable to find a better solution, and again in 1835 southern soldiers were transferred to maintain social order in the north. ${ }^{63}$

Military and judicial reforms were introduced in the early 1830 s in response to violent escalation and with the aim of boosting administrative efficiency. As turbulence spread across the Lower Mekong in 1833, Hue had no idea where to send northern prisoners. In fear of popular rebellion, Minh Menh first ordered them carefully guarded and then distributed among northern provinces. Aware of new uprisings in Thanh Hoa, Ninh Binh, Son Nam, Hung Hoa, and Cao Bang, the monarch was cautious with the treatment of prisoners and captured bandits. Blaming the chaos on his deceased generals (Duyet and Chat), he called for military reforms, including a reduction of flagbearers and purchasing Western gunpowder. ${ }^{64}$ More importantly, he proclaimed, 'recruitment of soldiers should focus on the real number' of those capable, not a collection of vagrants and outlaws. ${ }^{65}$ By limiting the recruitment of hired militiamen, non-registered males, and captured bandits into the army, Hue unintentionally drove many of these men into insurgency across the northern delta as it could neither exile them to the south, nor draft them into the army. Haunted by the prospect that hundreds, if not thousands, of them were concentrating in provincial prisons, Minh Menh constantly sent confidential edicts to acquire information, give instructions, and finally exile them in small groups to various northern provinces. ${ }^{66}$

This was a disaster. Infectious violence turned the river basin into a fertile breeding ground and sparked a new wave of uprisings from 1833 to 1837 , which will be discussed further below. Transregional militias established lowland-highland networks, particularly around the 'ring of insurgency' stretching from Thanh 
Hoa, Hung Hoa, Thai Nguyen, and Quang Yen. By 1834, Minh Menh decided that recruitment of vagrants and non-registered men was counterproductive and blocked his officials' proposals to draft more of them into the army. ${ }^{67}$

The waves of starving migrants flooding across the delta reflected another aspect of social conflict. The great 1824 famine displaced huge numbers from Hai Duong, Thai Binh, to Nam Dinh..$^{6}$ Unsurprisingly, the Phan Ba Vanh uprising sprang from this region. At its peak (1827), reports from Hai Duong showed that 108 villages had suffered demographic displacement, leaving 12,200 mau ( 1 mau $=0,36 \mathrm{ha}$ ) of rice fields abandoned. ${ }^{69}$ This indicates a profound relation between natural disasters, famine, demographic dislocation, and coercion. In autumn 1832, Thanh Hoa officials reported that groups of northerners asked for food and that 'many died along the way'. By the winter, 10 , ooo people travelled $150 \mathrm{~km}$ south from the delta's flooding centres. ${ }^{70}$ In the same year, 3 ,ooo people fled to Hai Duong. By the time the second memorial arrived in Hue, the number was 27,000. Officials were unable to feed this multitude and reported that many 'died along canals and rivers.' ${ }^{71}$

\section{Village rebellions and the deterioration of state power}

Despite official relief efforts, the annual waves of displaced villagers spurred various forms of crime, banditry, and militarization across the northern delta. Land flight from the low-lying provinces became common during periods of frequent seasonal flooding. ${ }^{72}$ Failures in water management accounted for twenty-seven floods between 1803 and 1861, the highest incidence in the millennium following Vietnamese control of the delta. ${ }^{73}$ These environmental and social factors ensured that the Nguyen's military victory over rival political elites in 1802 did not necessarily translate into their dominance over the countryside. Reliance on rural militias to exert authority over the villages unwittingly transferred control of taxation and army recruitment to the local gentry, who now pocketed a large share of taxation. ${ }^{74}$ Rather than centralizing and consolidating power, Nguyen policies contributed to social turmoil and signalled state deterioration, while the widespread withholding of taxes by villages, coupled with local militarization, indicated just how difficult it was for the central authorities to reach into the countryside.

The impact can be gauged by assessing how the state's judiciary and army responded to the two waves of violent unrest during the 1820 and 1830 . The early 1820 s saw a sharp rise in harsh punishments, with 450 new court cases in 1824 and 740 individual death sentences pending, including some who had been imprisoned since $1821 .{ }^{75}$ By winter 1826,800 prisoners in the north were awaiting the death penalty, while 200 were executed in $1828 .^{76}$ Alarmed, Emperor Minh Menh instructed local mandarins to treat his subjects more gently, and ordered those not already condemned to immediate execution to be held until his final verdict at the Autumn Assizes (thu tham)..$^{77}$ This failed to stem the growing use of the death penalty. ${ }^{78}$ The reliance on imprisonment and confinement pending execution resulted in 
overcrowded gaols, adding challenges to provincial administrations. Sixty convicts seized and destroyed Son Nam prison in $1830 .{ }^{79}$ Further riots followed in Thai Nguyen and Bac Ninh, responsible for Hue's order of prison inspections. The results were nevertheless disappointing and encouraged the damaging use of exile which, as we have already seen, contributed to the numbers of displaced persons joining the insurgents. ${ }^{80}$ Punitive measures also failed to rectify the judiciary's own problems. An imperial commission had executed one department chief and impeached ten officials for corruption at the Hanoi-based regional administration in $1827 .{ }^{81}$ However, demoralized by underfunding and dysfunctional administration, the judiciary continued to crumble during the 1830 s. $^{82}$

An examination of the Hue army underscores the central state's vulnerability. At first sight, Nguyen military power appeared impressive. According to some Western reports, the standing army numbered 50,000 men, rising to a peak of a 115,000 in the 1820 s. $^{83}$ Military 'innovation' was part of Hue's strategy to suppress its subjects and claim regional supremacy. Several dozen Westernstyle citadels were built in key towns. In 1824, Le Chat, as regional commander, ordered two constructed in Bac Ninh and Hai Duong. ${ }^{84}$ Chat then recruited 15,000 more troops, who were deployed in the provinces threatened by banditry. ${ }^{85}$ The most visible signs of Westernization appeared in soldiers' appearance and armament: by 1822, nearly half of the line troops were dressed in English woollen uniforms, carried European-style muskets, and were trained according to European manuals. ${ }^{86}$

French handguns and British gunpowder, however, were not the right answer to the turbulence. Security management in the delta's core was falling into local hands. ${ }^{87}$ Many of Gia Long's bandit-suppression campaigns were joined by regional strongmen who were encouraged to raise their forces. ${ }^{88}$ Hue launched multiple campaigns between 1802 and 1826 across the northern region against a wide range of opponents, comprising Tayson remnants, Le claimants, and rural militias. In 1808, Le Chat led a long operation against 3,00o insurgents in Ninh Binh. ${ }^{89}$ In that year alone, thirty engagements were fought from Thanh Hoa to Kinh Bac. ${ }^{90}$ The scale of these operations posed serious logistical and command challenges. Hue lay $700 \mathrm{~km}$ south of the northern delta - the main operating theatre - while rice and troops were collected from the Mekong Delta located roughly 1,700 km to the south of Hanoi. The state's armies marched back and forth to Thanh-Nghe in 1819 and 1824 against the Le claimants led by Duy Hoan, who had expanded into the delta through Ha Nam after 1816 by rallying support from local strongmen. ${ }^{91}$ Seventeen years after Hoan's execution in 1817 , his son Duy Luong led a new revolt from the mountains of Thanh Hoa-Ninh Binh into the delta, where he rallied local supporters. ${ }^{92}$ When Luong was killed, another Le claimant, Duy Hien, rebelled in 1836, underscoring Hue's inability to defeat its opponents.

Military modernization failed to address the underlying causes of rural revolts, which included corrupt officials and seasonal flooding. Hai Duong and Hung 
Yen provinces were badly affected by the Thai Binh and Red rivers, but official malfeasance concealed the consequences from Hue and hindered effective countermeasures. The court remained unaware that all nine counties of Hai Duong were suffering from famine and peasant displacement during $1824-27 .{ }^{93}$ The catastrophic flood of 1827 forced starving peasants to abandon hundreds of villages. ${ }^{94}$ Most moved east and south-east into the coastal region, already infamous as a bandit haven, where they swelled the number of insurgents to 5,000. Having defeated a Nguyen army on the coast, the insurgents allied with Chinese pirates, causing the first delta-wide crisis for the Nguyen since $1802 .{ }^{95}$

Haunted by the possibility that northern provincial citadels would be taken by the rebels, Emperor Minh Menh dispatched 2,00o troops to reinforce strategic garrisons and sent another force of 300 musketeers to confront the insurgents. ${ }^{96}$ Officials were instructed to communicate directly and confidentially with Hue rather than the Hanoi regional administration..$^{97}$ The reinforcements enabled the Nguyen army to capture the rebel stronghold of Nam Dinh, taking 760 prisoners, of whom 160 were beheaded and 400 sentenced to forced labour. ${ }^{98}$ Although Minh Menh attempted to relieve the consequences of famine and flooding by sending reputable officials to each village to placate peasants, the countryside was far from quiet: investigations revealed a list of 800 rebels, immediately prompting renewed punitive measures. ${ }^{99}$

Meanwhile, several thousand insurgents gathered in Bac Ninh and a pirate fleet of fifty ships launched attacks in Quang Yen. ${ }^{100}$ Hue responded by constructing a series of military posts, each manned by 30 to 100 soldiers along the $300 \mathrm{~km}$ of coastline from Nam Dinh to Quang Yen, to protect local communities from the pirates, prevent rice smuggling to China, and manage demographic mobility. ${ }^{101} \mathrm{Far}$ from reassuring people, the increased military presence sowed growing discontent among the rural population who interpreted Hue's actions as another form of coercive centralized control. The court now demanded quarterly reports on rice price and the security situation, and requisitioned sixty war elephants to enforce the delta. ${ }^{102}$ It also sent 1,476 cannons and 11,000 handguns to twelve provinces, representing a scale of arms distribution not seen since Vietnamese unification. ${ }^{103}$

A second wave of violence followed between 1832 and 1837 , caused partly by the continued efforts of Le claimants, but mainly by the government's failures in water management. Following flooding in 1825 and 1827, considerable resources were invested to improve flood defences, and $952 \mathrm{~km}$ of dykes were built by 1829 , representing the bulk of all construction under the first two Nguyen emperors. ${ }^{104}$ However, these endeavours failed to prevent serious floods in 1833 and 1835 . In frustration, Minh Menh deposed the dykes commission and summoned an empire-wide discussion on the hydraulic problem. Then, thousands of coolies were deployed in $1835-36$ to dig a $20 \mathrm{~km}$ canal through the most low-lying area. The project proved disastrous, bringing more water into the delta and submerging Hung Yen and Hai Duong provinces to a depth of $2 \mathrm{~m} .{ }^{105}$ 
This time the crisis was empire-wide. A military insurrection erupted in 1833, and the biggest citadel of the Lower Mekong, Phien An, was captured and held for three years. These rebels were assisted by five Siamese invading armies crossing the Vietnamese-Cambodian and Lao frontiers. ${ }^{106}$ In the north, around 650 insurgents reassembled in Son Tay and established close contact with discontented groups in the delta's rimland during the summer of $1834 \cdot{ }^{107}$ Meanwhile, $100 \mathrm{~km}$ to the south, a new Le claimant gathered thousands of followers in Ninh Binh and Thanh Hoa, and ethnic highlanders attacked provincial offices along the Sino-Vietnamese borders. This time, the rich, populous northern delta was threatened from three directions.

Sensing trouble, Minh Menh sent confidential requests to all senior provincial officials to provide information on bandits and outlaws. ${ }^{108}$ Regular troops and reserves in Ha Tinh and Hai Duong received orders to train and deploy in early 1834, while trusted southern troops were mobilized north to the delta. ${ }^{109}$ The emperor even took the rare step of summoning key ministers to establish a Privy Council to debate military matters. ${ }^{110}$ The Nguyen had clearly learned their lesson from 1825-27, and proceeded to isolate the delta from the hostile ethnic minorities in the surrounding highlands. The gunpowder trade was banned, and the sulphur and saltpetre mines were closed to cut the flow of arms and munitions to the delta. New networks of military posts and communications were set up along the coastline and the western corridor stretching from Son Tay to the south, blocking intruders from entering the lowland. ${ }^{111}$ Finally, in $1836-37$, some of the most capable generals were sent to pacify rural communities and display imperial sympathy for local inhabitants. These hand-picked commissioners not only conducted counter-insurgency operations, but also reorganized local administration, deposed corrupt officials, and boosted people's confidence. ${ }^{112}$

\section{Conclusions}

Although the Nguyen regime outwardly defeated both waves of rebellion, its apparent victory entailed relinquishing much of its authority in the countryside to the gentry and other armed 'bullies'. This encouraged a decentralizing cycle, placing tax revenues and army conscripts further from its reach. Hue remained an underfunded state relying on old-fashioned institutions and political philosophy to address the modern age's dynamic agenda. Like Qing China, Nguyen Vietnam failed to develop as a 'fiscal-military state' based on effective resource extraction for bureaucratic and military modernization. ${ }^{113}$

This chapter has argued that the idea of a society of stable villages projected by imperial political belief has deceived us about the Vietnamese state's ubiquitous control of violence and its ability to coerce at will. Certainly, the Nguyen state claimed a monopoly of legitimate violence, but we must look beyond central institutions to test this. The conventional interpretation portrays Asian 'rural communes' as small, static, and stagnant in time and space. ${ }^{114}$ As part of the narrative, 
modern Vietnamese nationalist historiography romanticizes the rural landscape with peace-loving residents and a reservoir of tradition. These approaches underestimate the role villages played in generating social violence and their durable capacity for violent resistance against the state. Early nineteenth-century Vietnam's villages indicate how vibrant human mobility and local militarization can provide counter-evidence to mainstream Western historical thought, including notions of Oriental despotism championed by Montesquieu, Hegel, Marx, and Wittfogel, as well as theorists of state-making, notably Max Weber and Charles Tilly, who, in both cases, place legitimate coercion in the hands of despots and state-builders. In these views, both violence and state-making are aligned as a common top-down process.

Local militarization in the Red River basin suggests that villages played a significant role in challenging a declining state in early modern East Asia, especially in densely populated deltas where peasant society was not, by any means, 'an inert sackful of potatoes', 115 but a highly interconnected and volatile social space. Vietnam's experience was far from unique. In rural China, the rise of local gentry-led militias between the 1790 os and 1860 s prepared the ground for the Qing's downfall. ${ }^{116}$ As Sidney Tarrow argues, there was a 'broad nineteenth-century' global disturbance which saw dynamic local forces 'organize their relations with the state, reconcile or fight out conflicts of interests and attempt to adapt politically to wider social pressures'. Jack Goldstone presents this as waves of state failures. ${ }^{117}$

Vietnam's experience is thus part of a wider pattern across the early modern world. Although, by the early nineteenth century, village rebellion was not a new phenomenon, the scale of violence soared to unprecedented levels. In the absence of urban centres, a burgeoning peasant mobility and growing rural market network made villages central to the generation and dissemination of conflict. By declaring war on the state, the countryside played an essential role in defining the violent culture of the age in their own terms. By grounding rural violence in its broader socioeconomic and cultural context, this chapter has revealed the boundaries between physical resistance as a daily 'weapon of the weak' and violence as a social collective response. ${ }^{118}$ The notion of rural violence not only demonstrates peasant economic and political behaviour, but also provides a window into their popular ideology, countryside politics, ideas of social order, law, and legitimacy during Vietnam's age of 'village rebellion'.

The violent deterioration of state-village relations not only weakened the Nguyen militarily, but forced central authority to partially retreat from rural areas, creating a vacuum filled by local chiefs and bullies who seized control of resource extraction. These local strongmen vividly illustrated that the state was not always able to monopolize violence in a world where coercion could be claimed by varied social forces to advance their own political visions. Dynastic decline from the $1790 \mathrm{~s}$ interrupted a long-standing if tense balance between state and society, and disrupted the restoration of order. As the state 'stepped back', villages acquired new 
roles to play on the political stage. They were neither 'peaceful' nor 'isolated'. They showed great capacity to generate collective violence and inflict damage on the central authority's foundations. Their use of violence was not simply a response to state repression but reflected a great historical transformation when the ruled themselves confronted the crisis of the times and fought for their own sociopolitical visions. The result was one of the most turbulent times in Vietnam's history. The Nguyen state survived the turmoil, but its continued failure to modernize would cost the Vietnamese dear over the following decades.

\section{Notes}

1 The author would like to thank Peter H. Wilson, Marie Houllemare, and Erica Charters for their thoughtful support and insightful comments over the course of writing and editing this chapter. The errors and deficiencies are my own. Đại Nam thư luc chính biên (Primary compilation of the Veritable Records of Imperial Vietnam) [hereafter DNTL] (Tokyo, 1963), II, 127: 2ob.

2 Ibid., II, 127: 21 .

3 Shijing (Book of Poetry): https://ctext.org/book-of-poetry/decade-of-bei-shan (accessed 10 Mar. 2018).

4 Out of 398 articles of the Nguyen Law Code, 50 concerned violent acts against the state and coercive crimes; 20 others involved murder. Vietnam National Library, Hoàng Việt Luật Lệ (Laws and Decrees of Imperial Vietnam), 1813, books 12-15, nos R.735, 738, 741, 743 .

5 DNTL, II, 101: 31a-b.

6 Ibid., 129: 1a-5a; Vietnam National Library, Thượng dụ huấn điêu (Edict of moral instructions), 1835, R.580.

7 DNTL, II, 104: 31b; P. Gourou, Man and Land in the Far East (London, 1975), p. 38.

8 C. Tilly, 'Reflections on the History of European State-Making', in C. Tilly (ed.), The Formation of National States in Western Europe (Princeton, 1975), p. 42.

9 See Khâm định tiễu binh lưỡng ki nghịch phỉ phương lược chính biên (Official compendium of rebel suppression in Northern territory), [hereafter KDBK] (Hanoi, 1836), VHv.2701.

10 M. Weber, From Max Weber: Essays in Sociology, ed. and trans. H. H. Gerth and C. Wright Mills (London, 1991), p. 78.

11 B. Davis, Imperial Bandits: Outlaws and Rebels in the China-Vietnam Borderlands (Seattle, 2017), p. 9.

12 N. Denzin, Y. Lincoln, and L. Smith (eds), Handbook of Critical and Indigenous Methodologies (Los Angeles, 2008), p. 563.

13 P. Mus, 'The Role of the Village in Vietnamese Politics', Pacific Affairs, 22:3 (1949), p. 265.

14 DNTL, I, 23: 7a-b.

15 P. Mus, Viet-Nam: Sociologie d'une guerre (Paris, 1952), p. 17.

16 P. Gourou, Les Paysans du Delta Tonkinois (Paris, 1936), p. 174; Y. Sakurai, 'Peasant Drain and Abandoned Villages in the Red River Delta Between 1750 and 1850', in A. Reid (ed.), The Last Stand of Asian Autonomies: Responses to Modernity in the Diverse States of Southeast Asia and Korea, 1750-1900 (London, 1997), p. 133. 
17 A. Monnier, 'Données Récentes sur la Population du Vietnam', Population, 36:3 (1981), p. 612.

18 See T. P. C. Nguyen, Thái áp - diên trang thời Trân (Noble plantations and estate in the Tran period) (Hanoi, 2002).

19 I. S. Yu, 'The Changing Nature of the Red River Delta Villages during the Lê Period (1428-1788)', Journal of Southeast Asian Studies, 32:2 (2001), p. 151.

20 S. L. Ngo, Đại Việt sủ ký toàn thu (Complete book of the historical record of Dai-Viet) [hereafter: DVSKTT], ed. J. H. Chen (Tokyo, 1984), p. 819.

21 See T. N. Li, Nguyen Cochinchina: Southern Vietnam in the Seventeenth and Eighteenth Centuries (Ithaca, NY, 1998); V. D. Liêm, 'Vietnam at the Khmer Frontier: Boundary Politics, 1802-1847', Cross-Currents: East Asian History and Culture Review, 5:2 (2016).

$22 \mathrm{Yu}$, 'Changing Nature', pp. 151-72.

23 G. Dutton, The Tay Son Uprising: Society and Rebellion in Eighteenth-Century Vietnam (Honolulu, 2006), pp. 130-47.

24 DVSKTT, p. 690; N. N. Nguyen (ed.), Một số văn bản điển chể và pháp luạt Viẹt Nam (Some problems of Vietnamese documents on legal institutions) (2 vols, Hanoi, 2006-09), I, p. 295.

25 A. Woodside, Vietnam and the Chinese Model (Cambridge, MA, 1988), pp. 46-8.

26 DNTL, II, 3: 11a-12b.

27 See my treatment of Hue's geopolitical disadvantage in V. D. Liêm, 'Nam Tiến' và cái bẫy địa lý của người Việt (Vietnamese 'marching south' and the trap of geography): www. bbc.com/vietnamese/forum-46007247 (accessed 20 Dec. 2018).

28 DNTL, II, 143: 5a.

29 Ibid., I, 25: 13b; I, 28: 10b. Local chiefs in Kien Xuong (Thai Binh), for instance, offered themselves as guides for the court army to launch a night's attack on the rebels on 17 January 1827. Châu bản triêu Minh Mệnh (Nguyen Vermilion records, Minh Menh reign) [hereafter MMCB], Trung tam Luu tru Quoc gia I, vol. 20, p. 248.

30 DNTL, I, 20: 26b; II, 41: 9a-b.

31 Ibid., II, 45: 26 a.

32 Ibid., I, 22: 12b.

33 Ibid., 34: 5a.

34 Ibid., II, 13: 23a-24b.

35 Ibid., 126: 22b-23a.

36 Ibid., 89: 3b.

37 Ibid., 95: 18a.

38 P. Q. Nguyen, Một số công trình sủ học Việt Nam (Some works on Vietnamese history) (Hochiminh-city, 2006), pp. 486-7.

39 DNTL, II, 103: 11a.

40 Ibid., 141: 19a-b.

41 Ibid., 165: 24a-b.

42 Ibid., 178: 22b; 180: 19a-b; 182: $10 b$.

43 J. K. Niu and Q.X. Li, 'Chinese "Political Pirates" in the Seventeenth-Century Tongking Gulf', in T. N. Li, N. Cooke, and J. Anderson (eds), The Tongking Gulf in History (Philadelphia, 2011). 
44 R. Antony, 'Violence and Predation on the Sino-Vietnamese Maritime Frontier, 14501850', Asia Major, 27:2 (2014). DNTL, II, 182: 15 a.

46 MMCB, 20: 212, 237; DNTL, II, 43: 23a-b.

47 DNTL, II, 182: 10b, 17a-b.

48 Ibid., 126: 22 b.

49 Sakurai, 'Abandoned Villages'.

50 DNTL, II, 95: 16b.

51 Đại Nam Chính Biên Liệt Truyện, Sơ tập (First Collection of the Primary Compilation of Biographies of Imperial Vietnam) (Tokyo, 1962), 22: 21a, 23b-24a.

52 DNTL, II, 26: 13a-14a.

53 MMCB, 6: 29-30; DNTL, II, 9: 16a; 16: 28a.

54 DNTL, II, 26: 17 b.

55 Ibid., 96: 15a-b; Choi Byung Wook, Southern Vietnam under the Reign of Minh Mạng (1820-1841): Central Policies and Local Response (Ithaca, NY, 2004), pp. 95-8.

56 DNTL, II, 162: 4a-b.

57 Ibid., 26: 13a-14b.

58 In early 1827 , for instance, northern officials complained that due to military campaign, they were unable to collect enough soldiers: MMCB, 20: 232.

59 DNTL, II, 18: 10 .

60 Ibid., 39: 25a.

61 Ibid., 37: 20a-b.

62 Ibid., 95: 16b.

63 Ibid., 142: 14b.

64 Woodside, Vietnam and the Chinese Model, p. 283.

65 DNTL, II, 125: 24a; 142: 12a-b.

66 Ibid., 114: 14a-b.

67 Ibid., 121: $12 \mathrm{a}$.

68 MMCB, 9: 18, 30; DNTL, II, 89: 3a.

69 Nguyen, Mot so cong trinh su hoc, p. 433.

70 DNTL, II, 88: 16b-17a; 90: 7b-8a.

71 Ibid., 89: 3a; 90: 6a.

72 O. Tessier, 'Outline of the Process of Red River Hydraulics Development During the Nguyen Dynasty', in M. Stewart and P. Coclanis (eds), Environmental Change and Agricultural Sustainability in the Mekong Delta (New York, 2011).

73 Ibid., p. 48.

74 DNTL, II, 51: $11 \mathrm{~b}$.

75 Ibid., 32: 1a.

76 Ibid., 40: 18b-19a; II, 53: 22b-23a.

77 Ibid., 26: $7 \mathrm{~b}$.

78 Ibid., 53: 22b.

79 Ibid., 66: 17 a.

80 Ibid., 68: 22a-b; 95: 16a.

81 Ibid., 43: 37a-b; 49: 6b.

82 Ibid., 165: 11b-12a. 
83 J. Crawfurd, Journal of an Embassy to the Courts of Siam and Cochin-China (Singapore, 1987 ed.), pp. 492-5. The dynastic record shows the number in 1841 was 212,290. DNTL, II, 220: $36 \mathrm{~b}$.

84 MMCB, 9: 39.

85 DNTL, II, 2: 28a-b.

86 V.Lieberman, Strange Parallels, vol. 1, Integration of the Mainland Southeast Asia in Global Context, c.80o-1830 (Cambridge, 2003), p. 454.

87 DNTL, I, 36: 8b-9a; 37: 1b-2a.

88 Ibid., II, 19a-b.

89 Ibid., 35: 5a-6b.

90 Ibid., 34: 4b; 35: $10 b$.

91 Ibid., 54: 14b-15a.

$92 K D B K$, books 1, 9.

93 DNTL, II, 40: 19a-b.

94 Ibid., 37: 4a-b.

95 Ibid., 42: 19 .

96 Ibid., 42: 21b-22a.

97 Minh Menh, Ngự chế văn, Sơ tập (Imperial writings, first collection), 1834, Vien Han Nom, A. 1723, book 10: 13b-14b; DNTL, II, 43: $16 \mathrm{~b}$.

98 DNTL, II, 43: 34b, 36a.

99 Ibid., III, 43: 36b-37a.

100 Ibid., II, 43: 38 b.

101 Ibid., 60: 29a-b; R. Antony, 'Giang Binh: Pirate Haven and Black Market on the SinoVietnamese Frontier, 1780-1802', in J. Kleinen and M. Osseweijer (eds), Pirates, Ports and Coasts in Asia: Historical and Contemporary Perspectives (Singapore, 2010).

102 DNTL, II, 46: 16b.

103 Ibid., 67: 14b; 101: 31a-b.

104 144,5 km were built in twenty-six years of the Gia Long and Minh Menh reigns. Tessier, 'Outline of the Process', p. 51.

105 D. D. Hung, 'Vấn đề trị thủy ở Hưng Yên dưới thời Nguyễn (Problems with hydraulic engineering works in Hung Yen Province during the Nguyen dynasty)', Nghien Cuu Lich Su, 5:270 (1998), pp. 44-5.

106 Liêm, 'Vietnam at the Khmer Frontier', passim.

107 DNTL, II, 128: 10a.

108 Ibid., 91: 27b.

109 Ibid., 116: 15 a.

110 Ibid., 142: 14 b.

111 Ibid., 189: 31a.

112 Ibid., 180: $16 \mathrm{~b}$.

113 See J. Glete, War and the State in Early Modern Europe: Spain, the Dutch Republic and Sweden as Fiscal-Military States (London, 2002); P. K. O’Brien and P. Hunt, ‘The Rise of a Fiscal State in England, 1485-1815', Historical Research, 66:160 (1993).

114 T. Shanin, Late Marx and the Russian Road: Marx and the Peripheries of Capitalism (New York, 1983), pp. 111-12.

115 K. Marx, The Eighteenth Brumaire of Louis Bonaparte (New York, 2008 ed.), p. 84. 
116 P. A. Kuhn, Rebellion and its Enemies in Late Imperial China: Militarization and Social Structure, 1796-1864 (Cambridge, 1970).

117 S. Tarrow, 'Introduction', in S. Tarrow, P. Katzenstein, and L. Graziano (eds), Territorial Politics in Industrial Nations (New York, 1978), p. 1.

118 Term used byJ. C. Scott, Weapons of the Weak: Everyday Forms of Peasant Resistance (New Haven, CT, 1985). 